\title{
Logistics Service Quality as Mediation of The Effect of Information Systems on Supply Chain Relationship
}

\author{
Irfan Nur Toufik ${ }^{1}$, Ika Nurul Qamari ${ }^{2 *}$ \\ ${ }^{12}$ Department of Management, Faculty of Economics and Business, Universitas Muhammadiyah Yogyakarta, \\ Yogyakarta, Indonesia \\ *Correspondingauthor.Email: ika_nr@umy.ac.id
}

\begin{abstract}
This study examines information systems' effect on supply chain relationships with logistics service quality as a mediating variable. The study was conducted on customers of a freight forwarding company in the Special Region of Yogyakarta. This study's sampling method was non-probability sampling, which was a purposive sampling technique through online questionnaires. The sample used in this study was 160 respondents aged 18 years old and over and had experience using freight forwarding services at least twice in the past six months. Data analysis implemented structural equation modeling in Amos 2.4. This study proved that information systems did not directly have a significant effect on supply chain relationships but indirectly have a positive and significant effect on supply chain relationships through the logistics service quality as a mediation.
\end{abstract}

Keywords: Information systems, Logistics service quality, Supply chain relationship.

\section{INTRODUCTION}

The growth of technology has disrupted various business matters. This situation has an impact on increasing internet users in Indonesia. Data released by the Association of Indonesian Internet Service Providers (APJII) in 2017 to 2019 showed that Internet users in Indonesia increased by $54.86 \%$, equivalent to 171.17 million people connected to the internet. Internet users' high growth is an excellent potential to support Indonesia's digital economy, e-commerce. Consumer behavior towards the e-commerce community in Indonesia has increased slightly higher.

Business buying and selling goods through online platforms will require freight forwarders. Freight forwarders, as one type of transport company, have an essential role in distributing a company's product distribution between one region and another [13]. Logistics is also related to planning, organizing, and coordinating the flow of materials, information, energy, money, and values in a logistics system [6]. It affects an increasing forwarding business in Indonesia, especially in Yogyakarta, such as JNE Express, J \& T Express, rides, Beautiful logistics, Herona Express, and Kafila Cargo.
The growth of several businesses, sometimes the delivery, ignores other matters related to service quality. It is proven in customer complaints related to the delivery of the goods are delayed, damaged, or lost. Logistics service quality is the activities carried out by freight forwarders consistent with shipping quality and efficiency [11]. Quality of service is an attitude of comparing consumers' service quality expectations with a company's consumer-perceived performance [17]. In other words, service quality is the customer's perception of the service it receives, whether it has conformity to customer expectations [2]. Consumer satisfaction on logistics service quality will align with the customer's attitude to reuse services rendered.

One-third of strategic alliances fail due to a lack of trust among trading partners [15]. The supply chain performs a successful relationship based on high levels of trust and commitment. Moreover, disclosing corporate information systems, such as making an expedition against consumer applications, websites, and personal contact relationships, will fully convey all the information. Some of the activities that can be monitored by the consumers are an e-shipping, mobile tracking system, customer relationship management (CRM), claims handling system [16]. In the same field, JNE has the most number of customers among the other 
competitors. Besides, JNE also was awarded the Indonesia Digital Hot Brand Award 2018 from Franchiseglobal.com \& TRAS n Co Research. JNE has received this award three times since 2016. It is why the JNE becomes the object, and its customers become the subject of study by researchers.

\section{LITERATURE REVIEW}

\subsection{Relationship the Information System of the Logistics Service Quality}

Information systems is an activity of organized procedures. When it is executed, it will provide information to support decision making and control in the organization [3]. Information is possible to predict with better accuracy to make decisions [1, 24]. Disclosure freight forwarders manage and provide information regarding the consumer's delivery of goods to become an important point.

The company's information systems are measured from ordering shipments through online (e-shipping) related tariffs and the goods' delivery point. Further search information items have been shipped to the point where gadgets can access it (mobile tracking system). Besides, the customer relationship with the company (customer relationship management) provides information to customers. The company's efforts to better serve the complaint and structure (claims handling system) are also a quality measurement tool system existing at the shipping company.

In previous research, the availability of information delivery as an indicator of the company's information systems expedition positively affects service delivery [22]. The availability of information by employees (customer relationship management) also affects the quality of logistics services to customers satisfied [9,12]. Based on the logic of the relationship between information systems and logistics service quality supported by several previous studies, the first research hypothesis is as follows.

H1: The information system positively affects customer logistics service quality at JNE.

\subsection{Relationship between Logistics Service Quality on Supply Chain Relationship}

Companies, including venture ones, hold logistics service quality to meet and respond to consumers' needs of goods and services by optimizing the network chain of goods and services up to the customer on time. Logistics service quality can be regarded as the primary purpose of delivering goods according to customer expectations. In the logistics service quality, several indicators can measure the quality of the delivery. They are the availability of product services (order release quantities), the information obtained from customer-related goods shipped (information quality), procedures for requesting delivery (ordering procedures). Logistic service quality positively affects customer satisfaction, where customer satisfaction itself is one indicator of the supply chain relationship [14]. Timeliness is an indicator of logistics service quality has a positive effect on the supply chain relationships [21]. Logistics service quality has a positive effect on customer satisfaction that is part of the relationship [4, 5, 19]. Based on the logic of the relationship of logistics service quality to the supply chain relationships based on several previous studies supported the research, the second hypothesis is as follows.

H2: Logistic service quality has a positive effect on the supply chain to the customer relationship JNE.

\subsection{The relationship between the Information System of the Supply Chain Relationship}

Currently, the system has many benefits for the information for any company. This information system will provide information to support decision making and control of the organization. Dimensions related to information systems include system quality, information quality, and service quality [18]. In practice, JNE has information systems that play a role in the (e-shipping) related tariffs, the goods delivery point, the point of outlets' existence, the availability of search information accessed through the gadget goods (mobile tracking system). From this information, the system can also support the claim handling system's activities, where the system will serve JNE complaints from consumers related to the delivery of goods. The better the information system is, the better the claim handling system's increase or support will be. The availability of information from customer relationship management employees is one indicator of the information system that affects trust [12] to satisfy the customer, hoping to use its services again. Based on the logic of the relationship between information systems with supply chain relationships, and supported by several previous studies, the third research hypothesis is as follows.

H3: Information system positively affects the supply chain relationship

\subsection{The relationship between the Information System of the Supply Chain Relationship with the Logistic Service Quality as mediation}

Information Systems is an activity of organized procedures. When it is executed, it will provide information to support decision making and control in the organization. Information systems in shipping companies have indicators such as the ease of ordering shipments through online (e-shipping) related tariffs, the goods delivery point, the point of the existence of outlets, the 
availability of search information accessed through the gadget goods (mobile tracking system). The existing indicators that will affect the company's quality logistic services, what it goes well and satisfaction for customers create a good relationship. Customers and consumers should agree to determine quality standards [8]. Successful supply chain performance is characterized by a high level of trust and a strong commitment among supply chain partners. Dimensions of Supply Chain Relationship include trust and commitment [20]. Besides, the presence of it makes the company's reputation rise. The way companies deal with the problem will also affect the supply chain relationship.

Previous research stated that customer relationship management employees' availability was one indicator of the information system affecting the quality of logistic services to the satisfied customer resulting sense of confidence $[9,12]$. From the sense of trust that makes customers loyal and expedition company's reputation will rise.

Based on the logic of the relationship between information systems and supply chain relationship with logistic service quality as mediation and supported by several previous studies, the fourth research hypothesis is as follows.

H4: Information system positively affects the supply chain relationship is mediated logistics service quality at JNE customers.

\section{METHODS}

Respondents were customers of shipping companies in the Special Region of Yogyakarta. This study used a purposive sampling technique [23]. The requirements stipulated in selecting respondents as a sample were consumers who had used the freight service at least two times in the last six months. The age of the respondents was at least 18 years old. The number of samples in this study was 160 respondents.

This study implemented primary data from questionnaires filled out by respondents. This research's variables were logistics service quality, information systems, and supply chain relationships, as measured by a questionnaire using a Likert scale with the average answer 1-7. This scale described the rank answers from strongly disagree to strongly agree. The research instrument was based on each variable's indicators that included logistics service quality, information systems, and supply chain relationships.

The technique used to test the hypothesis in this research was Structural Equation Modeling (SEM) with AMOS [7]. Some issues that needed to be tested included confirming the dimensionalization of various indicators to a construct, test compliance/accuracy of a model based on empirical data studied, the model's suitability, and causality between factors built/observed in the research model. The researchers also inspected every item questionnaire using validity and reliability tests to determine whether the item already revealed whether the data of variables appropriate and consistent.

\section{RESULT \& DISCUSSION}

\subsection{Result}

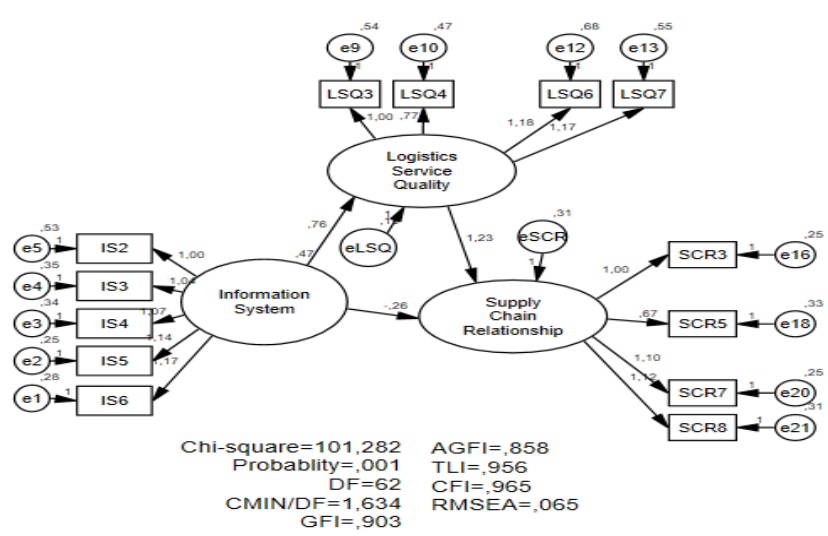

Figure 1: Relationship LSQ, IS, and SC

The indicators for each research variable are presented in Table 1. Logistic service quality includes 8 indicators, the information system consists of 6 indicators, and the supply chain relationship is measured by 8 indicators. Before getting this fit result, the researchers modified the model by removing the indicators LSQ1, LSQ2, LSQ5, IS1, SCR1, SCR2, SCR4, SCR6 because of the indication of wordiness or often referred to as similarity of meaning with other indicators on the same variable [24]. Figure 1 shows the results of Structural Equation Modeling (SEM) testing. It confirms the full model and has six fit indexes, among others Chi-Square 101.262, the probability value of 0.01 , the value CMIN / DF at 1.634, GFI value of 0.903 , AGFI value of 0.858 , TLI value of 0.956 , the value of CFI amounted to 0,965 , the value of RMSEA of 0.65 . Thus, the research model is acceptable and meets the selected criteria.

Table 2 shows the correlation coefficients of the three variables studied, logistic service quality, information systems, and supply chain relationships. The results of hypothesis testing prove that all of the proposed hypotheses reinforce logistic service quality as a mediation of the effect of information systems on supply chain relationships. Table 2 presents the relationship and significance of each variable. The relationship between information systems and logistic service quality shows that the results of the calculation of structural lines of a positive and significant relationship can be seen at the value of $t=6.382>1.96$, with a significant value 0.000 
Table 1. Test Validity and Reliability

\begin{tabular}{|c|c|c|c|c|}
\hline Variables and Indicators & $\begin{array}{l}\text { Loading } \\
\text { Factor }\end{array}$ & Information & $\mathbf{C R}$ & Information \\
\hline \multicolumn{5}{|l|}{ Logistics Service Quality } \\
\hline Providing on-demand services & 0.750 & valid & \multirow{7}{*}{0.880} & \multirow{7}{*}{ reliable } \\
\hline The website provides clear information & 0.633 & valid & & \\
\hline The procedure is easy and fast & 0.771 & valid & & \\
\hline $\begin{array}{l}\text { The number and types of delivery } \\
\text { according }\end{array}$ & 0.695 & valid & & \\
\hline Good stuff condition (not broken) & 0.648 & valid & & \\
\hline Responses to the problem & 0.627 & valid & & \\
\hline Timely Delivery & 0.696 & valid & & \\
\hline \multicolumn{5}{|l|}{ Information System } \\
\hline Ease of access to the system & 0.717 & valid & \multirow{6}{*}{0.84} & \multirow{6}{*}{ reliable } \\
\hline System response time & 0.690 & valid & & \\
\hline Availability of information delivery & 0.788 & valid & & \\
\hline Availability rates & 0.776 & valid & & \\
\hline $\begin{array}{l}\text { The availability of location information } \\
\text { office }\end{array}$ & 0.830 & valid & & \\
\hline Accuracy of information & 0.809 & valid & & \\
\hline \multicolumn{5}{|l|}{ Supply Chain Relationship } \\
\hline Satisfied with the transaction experience & 0.857 & valid & \multirow{8}{*}{0.94} & \multirow{8}{*}{ reliable } \\
\hline Feeling happy to have chosen & 0.842 & valid & & \\
\hline Feeling a wise choice & 0.842 & valid & & \\
\hline Confidence companies can serve & 0.855 & valid & & \\
\hline Confidence trustworthy enterprise & 0.839 & valid & & \\
\hline Confidence companies can protect & 0.734 & valid & & \\
\hline Remains a customer of the company & 0.831 & valid & & \\
\hline Recommend to others & 0.828 & valid & & \\
\hline
\end{tabular}

Table 2. Test Validity and Reliability

\begin{tabular}{cccccc}
\hline Hypothesis & Research hypothesis & estimate & $\mathbf{t}$ & $\mathbf{P}$ & Label \\
\hline H1 & $\begin{array}{c}\text { Information System -> } \\
\text { Logistics Service Quality }\end{array}$ & 0,765 & 6.382 & $* * *$ & Significant \\
H2 & $\begin{array}{c}\text { Logistics Service Quality -> } \\
\text { Supply Chain Relationship }\end{array}$ & 1.233 & 5.039 & $* * *$ & Significant \\
H3 & $\begin{array}{c}\text { Information System -> Supply } \\
\text { Chain Relationship }\end{array}$ & -0.257 & -1.284 & 0.2 & No effect \\
\hline
\end{tabular}

$<0.05$. This proves the first hypothesis can be accepted. Relationship Logistics Service Quality on Supply Chain Relationship shows the results of the calculation of structural lines indicating a significant and positive relationship in the value $\mathrm{t}=5.039>1.96$ with an enormous value of $0.000<0.05$. It means that the second hypothesis can be accepted.

Relationship Information System to direct Supply Chain Relationship shows that a negative structural path's calculation results do not affect. This result can be seen in the value $(\mathrm{t}=-1.284>1.96)$ with significant $(0.2$ $<0.05)$. Thus, the third hypothesis is rejected.

Hypothesis 4 was tested with different test methods between a partial and full mediation model with the ChiSquare value of both models by a margin of $0.541 \mathrm{DF}=$ 1 (168-167). The figure indicates a significant difference between the two models. Although the value of the difference a little, this number has a different meaning. This study presents that hypothesis 4 is supported, which means that Logistics Service Quality mediates the effect of information systems on Supply Chain Relationship.

\subsection{Discussion}

This study aims to prove the relationship between logistics service quality, information systems, and supply chain relationships. This study shows that the information system significantly and positively influences logistics service quality. Previous studies supported the results of this study. The availability of information delivery as an indicator of the company's information systems expedition positively influenced service delivery [22]. It also supported research that employees' availability (customer relationship management) affected the quality of logistics services perceived by consumers $[9,12]$.

Subsequent studies confirmed that logistics service quality positively and significantly influenced the supply chain relationship. It supported several previous studies that logistics service quality positively affected customer satisfaction [14], where customer satisfaction itself was 
one indicator of the supply chain relationship. The other study reported that timeliness was an indicator of logistics service quality where it positively affected supply chain relationships [21].

The results further prove that the information system does not affect the direct supply chain relationship. This study's results contradict research stating that information systems' availability on customer relationship management was one indicator of information systems that affected logistic service quality to feel satisfied and self-confident. [12]. According to the researchers, this result is due to differences in the object of research. If the previous research object, PT. Gemilang Libra Logistics had customers business to business, while the JNE has complex types of consumers, such as customers to customers or business to customers. Therefore, this factor may have affected the dimensions such as ease of procedure demand delivery (ordering procedures) becoming critical. PT. Gemilang Libra Logistics only had several consumers and did not have complex types of customers compared to JNE.

This study proves that there is an influence indirectly through logistics service quality as mediation. These results support previous research that the availability of information affected the quality of logistic services to customers' satisfaction and raised the confidence to use them again. Thus, this shipping company's reputation would rise [9]. The logistics service quality should be improved to influence the supply chain relationship's information system directly.

\section{CONCLUSION}

This study presented new empirical research by proving logistics service quality as a variable that mediated the relationship between information systems and supply chain relationships. Thus, this result showed that information systems were needed as support for organizational survival. When the company's information system is not profitable for consumers who have experienced and trusted good logistics services, it will be considered a fraction of the risk they receive because it builds trust as logistic service quality. It is indicated by the delivery of services on demand, a website that provides clear information., easy and fast procedures, the right number and type of delivery, good stuff condition, responding to problems faced well, and delivery times according to schedule.

This study examined the relationship between three variables indicating that logistic service quality would further increase information systems' influence on supply chain relationships.

Future research can refer to this research by adding other variables that influence supply chain relationships, such as social values and ethics, interaction capabilities, trust, and supply chain networks.

\section{ACKNOWLEDGMENTS}

The authors would like to thank all respondents who participated in taking their time and were willing to fill out the questionnaire for this study and also thanked the leadership of the freight forwarding company who had permitted so that this study could be carried out well.

\section{REFERENCES}

[1] Adami, C., What is information. Philos. Trans. R. Soc. Math. Phys. Eng. Sci. 374, 20150230, 2016, DOI: https://doi.org/10.1098/rsta.2015.0230

[2] Agyapong, G.K.Q., The Effect of Service Quality on Customer Satisfaction in the Utility Industry - A Case of Vodafone (Ghana). International Journal of Business and management. 6, 2011, pp. 203-210. DOI: https://doi.org/10.5539/ijbm.v6n5p203

[3] Astuti, P.D., Drug Sales Information System at Apotek Jati Farma Arjosari. 3(6), 2011, pp. 34-39. DOI: http://dx.doi.org/10.3112/speed.v3i4.1217

[4] Bianda, Versa., Hartono, Subagio. The Influence of Logistics Service Quality on Customer Satisfaction Emco Cat PT.Satriakarya Adiyudha (PT.SKAY). Petra's Journal of Marketing Management 2(2), 2014.

[5] Denny, Kusuma. The Influence of Logistics Service Quality on Satisfaction and Loyalty at PT Tiki Jalur Nugraha Eka Kurir. University of Surabaya Student Scientific Journal. 3(2), 2014.

[6] Gyorgy, K., Sebastian, K., New Logistics and Production Trends As The Effect of Global Economy Changes. Polish Journal of Management Studies 14, 2016, pp. 115-126, DOI: http://10.17512/pjms.2016.14.2.11

[7] Ghozali, I., Application of Multivariate Analysis with IBM SPSS Program 24, 8th ed. Research Agency of Universitas Diponegoro, 2016.

[8] Griffith, D.A., Harvey, M.G., Lusch, R.F., Social exchange in supply chain relationships: The resulting benefits of procedural and distributive justice. J. Oper. Manag. 24, 2006, pp. 85-98 DOI: https://doi.org/10.1016/j.jom.2005.03.003

[9] Hidayat, R., n.d. Goods Expedition Information System With E-CRM Method To Improve Customer Service. 4(5). 2014, DOI: http://dx.doi.org/10.38101/sisfotek.v4i2.50

[10] Ho, J.S.Y., Teik, D.O.L., Tiffany, F., Kok, L.F., Teh, T.Y., Logistic Service Quality among Courier Services in Malaysia 5, 2012.

[11] Hyun Mi Jang, Peter B. Marlow, Kyriaki Mitroussi, The Effect of Logistics Service Quality on Customer Loyalty through Relationship Quality in the Container Shipping Context. Transportation Journal. 52, 2013, pp. 493-521. https://doi.org/10.5325/transportationj.52.4.0493

[12] Iriandini, A.P., Yulianto, E., Mawardi, M.K., n.d. The Influence of Customer Relationship Management (CRM) on Customer Satisfaction and 
Customer Loyalty (Survey on Customers of PT. Gemilang Libra Logistics, Surabaya City) 8, 2015.

[13] Islam, D.M.Z., Fabian Meier, J., Aditjandra, P.T., Zunder, T.H., Pace, G., Logistics and supply chain management. Res. Transp. Econ. 41, 2013, pp. 316. https://doi.org/10.1016/j.retrec.2012.10.006

[14] Japarianto, E., The Effect of Logistics Service Quality on Customer Retention with Customer Satisfaction as an Intervening Variable in the Sea Expeditioning Industry in Surabaya. Journal of Marketing Management 12(1), 2018, pp. 25-32. DOI: https://doi.org/10.9744/pemasaran.12.1.25-32

[15] Kwon, I.-W.G., Suh, T., Factors Affecting the Level of Trust and Commitment in Supply Chain Relationships. J. Supply Chain Manag. 40, 2004, pp. 4-14. https://doi.org/10.1111/j.1745493X.2004.tb00165.x

[16] Niveen El Saghier, Hoque Bhuiyan, M., Service Quality Dimensions and Customers' Satisfactions of Banks in Egypt. World Business Institute Australia, Australia, 2013.

[17] Petter, S., DeLone, W., McLean, E., Measuring information systems success: models, dimensions, measures, and interrelationships. European journal of information systems. 17, 2008, pp. 236-263. DOI: https://doi.org/10.1057/ejis.2008.15

[18] Raymond, Hendry., Yohji, Ericko. The influence of Logistic Service Quality on customer satisfaction and loyalty of Kentucky Fried Chicken in Surabaya. Journal of Hospitality and Service Management, 2015

[19] Razavi, S.M., Abdi, M., Amirnequiee, S., Ghasemi, R., The Impact of Supply Chain Relationship Quality and Cooperative Strategy on Strategic Purchasing 11, 2016, pp. 6-15.

[20] Sakti, B.J., n.d. Analysis of the Influence of Service Quality, Timeliness of Delivery and Facilities on Customer Satisfaction (Study at J\&T Express Semarang City) 9, 2018, pp. 137-144.

[21] Simamora, V., Susanti, E., The Effect of WebBased Tracking System Service Quality on Customer Satisfaction through Consumer Risk Perception of JNE Cilincing Products 15, 2017.

[22] Sugiyono, 2015. Combination Research Methods (Mix Methods). Bandung: Alfabeta, 2015.

[23] Weiss, M., Newman, A.M., 2011. A guide to writing articles in energy science. Applied Energy 88, 2011, 3941-3948. DOI: https://doi.org/10.1016/j.apenergy.2011.04.007

[24] Qamari, I.N., Widowati, R., Fauziyah, Kurnia, F., The Use of Communication and Information Technology Innovation Among Micro, Small and Medium Enterprises, International Journal of Scientific Research and Management. 6(11), 2018, pp. 320-326. DOI: 10.18535/ijsrm/v6i11.sh01 